\title{
Dorobek badań nad skarbowościq Polski międzywojennej
}

\section{Stand der Forschung zum Finanzwesen Polens in der Zeit zwischen den Weltkriegen}

1. Uwagi ogólne. 2. Opracowania całościowe. 3. Budżet i prawo budżetowe. 4. Podatki bezpośrednie. 5. Cło i monopole skarbowe. 6. Pożyczki wewnętrzne i zagraniczne. 7. Administracja skarbowa i kontrola finansowa. 8. System finansowy przedsiębiorstw państwowych. 9. System pieniężny. 10. Banki i kredyt. 11. Finanse komunalne.

1. Einführende Bemerkungen. 2. Synthesen. 3. Staatshaushalt und Staatshaushaltsrecht. 4. Direkte Steuern. 5. Zoll und Finanzmonopol. 6. Inlands- und Auslandskredite. 7. Finanzadministration und Finanzkontrolle. 8. Finanzsystem der Staatsunternehmen. 9. Geldsystem. 10. Die Banken und der Kredit. 11. Kommunalfinanzen.

1. W 1970 r. Z. Landau dokonał przeglądu osiągnięć i braków badań nad historią finansów II Rzeczypospolitej, przeprowadzonych po II wojnie światowej ${ }^{1}$. Obrazując główne kierunki badawcze, podkreślił niezbędność źródłowego poznania owej problematyki dla wieloaspektowej analizy sytuacji gospodarczej Polski międzywojennej oraz przeobrażeń ekonomiczno-finansowych, jakie dokonaly sie w Polsce od 1944 r. Wskazal jednocześnie $\mathrm{m}$. in., że badania nad historią finansów rozwijają się wolno, prowadzone są przeważnie na marginesie innych badań i dotyczą często problemów drugorzędnych. Zaakcentował ,uderzającą" dominantę prac przyczynkarskich nad monografiami o charakterze całościowym oraz potrzebe utworzenia ośrodka, który koncentrując się na historii finansów międzywojennych i koordynując badania $w$ tym zakresie, przyczyniłby się do szybkiej zmiany na korzyść owej sytuacji².

Niniejsze zestawienie obejmuje publikacje powstałe po II wojnie światowej, z pominięciem opracowań ujmujących ową problematykę drugoplanowo,

${ }^{\prime}$ Zob. Z. La ndau, Historia finansów II Rzeczypospolitej w publikacjach powojennych, „Finanse" 1970, nr 3, s. 49-60.

${ }^{2}$ Ibidem, s. 50. 
wśród innych poruszanych zagadnień. $Z$ prac przedwojennych sygnalizuje jedynie te, które najpełniej obrazują poszczególne działy skarbowości II Rzeczypospolitej. Należy bowiem zgodzić się ze stanowiskiem Z. Landaua, że prace opublikowane w Polsce przedwrześniowej nie mogły objąć całego okresu międzywojennego; pisane były bez niezbędnej perspektywy historycznej, potrzebnej dla formułowania wyważonych opinii o badanych zjawiskach, i częstokroć miały charakter albo nazbyt apologetyczny, albo nazbyt krytyczny ${ }^{3}$; nie podejmowały tematów, które uznawano wówczas za tajne. Nadto prace powojenne mogły powstawać $w$ następstwie zastosowania znacznie udoskonalonych metod badania przeszłości ${ }^{4}$.

2. Najpełniejszym, przedwojennym opracowaniem obrazującym całość finansów i prawa finansowego II Rzeczypospolitej jest podręcznik I. Weinfelda pt. Skarbowość polska ${ }^{5}$, którego ostatnie, kompletne wydanie (czwarte) ukazało się w 1935 r. Autor przedstawił najważniejsze zagadnienia odzwierciedlające stan polskiej skarbowości do 1933 r. (dzieje skarbowości po odzyskaniu niepodległości, źródła prawa skarbowego, władze skarbowe, budżet, kasowość i rachunkowość, wydatki, dochody, dhugi, waluta, podatki, opłaty, clo, akcyzy, monopole, przedsiębiorstwa i majątki, finanse samorządu, skarbowość Śląska). W ramach piątego wydania owego podręcznika (podzielonego na trzy tomy) zdołano wydać do końca Polski przedwrześniowej dwa tomy ${ }^{6}$. Ujmują one całość omawianej problematyki, $\mathrm{z}$ wyjątkiem finansów komunalnych oraz zagadnienia przedsiębiorstw państwowych i majątku państwowego, zaplanowanych jako przedmiot tomu 3., wydaniu którego przeszkodzil wybuch wojny. Jak ocenil $\mathrm{K}$. Ostrowski, prace I. Weinfelda przedstawiaja $z$ niezwykla dokladnościa material normatywny, komentuja go w oparciu o orzecznictwo N.T.A. i glosy do poszczególnych orzeczeń, ilustrujq szeregiem zestawień statystycznych i podaja szczególowo literature przedmiotu?.

Sporo informacji o skarbowości II Rzeczypospolitej (administracja skarbowa, cło, monopole, podatki pośrednie, podatki bezpośrednie) dostarcza też Kalendarz Skarbowy na 1939 r. pod redakcją Z. Machaja ${ }^{8}$.

Wśród publikacji powojennych walor najbardziej całościowych mają prace K. Ostrowskiego: Polityka finansowa Polski przedwrześniowej oraz Finanse $i$ prawo finansowe zamieszczona $\mathrm{w}$ części 1 . Historii państwa i prawa

${ }^{3}$ Ibidem, s. $50-51$.

${ }^{4}$ Loc. cit..

${ }^{5}$ I. W e in feld, Skarbowość polska, Warszawa 1935.

${ }^{6}$ I. We in feld, Skarbowość polska, t. 1 i 2, wyd. V, Warszawa 1939.

${ }^{7}$ K. Ostrowski, Finanse $i$ prawo finansowe, [w:] Historia państiva $i$ prawa Polski 1918-1939, cz. I, red. F. Ryszka, Warszawa 1962.

* Warszawa 1939.

${ }^{9}$ K. Ostrowski, Polityka finansowa Polski przedwrześniowej, Warszawa 1958. 
Polski $1918-1939^{10}$. Pierwsza z publikacji omawia wpierw „bezbudżetowy” charakter gospodarki państwa, a następnie, w ujęciu chronologicznym, zagadnienia budżetu państwa, polityki podatkowej, pożyczek i długów państwowych, kwestie walutowe, finanse samorządowe. Rozważania te poprzedza analiza ,tta społeczno-ekonomicznego". Charakteryzując owe kwestie, Autor wyodrębnił następujące okresy: wielkiej inflacji (1918-1923), poinflacyjnego osłabienia gospodarczego (1924-1926), ożywienia gospodarczego (1927-1928), wielkiego kryzysu gospodarczego (1929-1935) oraz pokryzysowej aktywizacji gospodarczej (1936-1939). Jak zauważył Z. Landau, K. Ostrowski nie wykorzystal $w$ tej pracy dostępnych archiwaliów i w niektórych wypadkach zamieścił oceny nazbyt jednostronne $i$ przesadnie pesymistyczne ${ }^{11}$.

$\mathrm{W}$ drugiej $\mathrm{z}$ wymienionych prac $\mathrm{K}$. Ostrowski dokonal wyboru literatury finansowo-prawnej Polski przedwrześniowej, a następnie przedstawił w ujęciu chronologicznym szeroki wachlarz zagadnien, który czyni ową publikację zwięzlym, encyklopedycznym przewodnikiem po problematyce skarbowo-walutowej II Rzeczypospolitej ${ }^{j 2}$.

Przedstawiając opracowania całościowo ujmujące problematykę finansów II Rzeczypospolitej, należy wskazać jeszcze na artykuły: K. Ostrowskiego Finansowe oblicze międzywojennej niepodleglości ${ }^{13}$, Z. Landaua Skarbowość Drugiej Rzeczypospolitej (1918-1939)14 oraz U. Zagóry-Jonszty Problemy finansowo-gospodarcze Drugiej Rzeczypospolitej ${ }^{15}$. Z kolei działalność prawodawczą $w$ dziedzinie finansów w omawianym okresie przedstawil C. Kosikowski ${ }^{16}$.

Obok publikacji ujmujących całość finansów Polski międzywojennej trzeba by wymienić opracowania przybliżające ową problematykę w poszczególnych okresach. Skarbowość państwa w latach 1918-1920 przedstawił Z. Landau ${ }^{17}$, zaś lata 1918-1923 są opisane w książce Z. Landaua i J. Tomaszewskiego zatytułowanej $W$ dobie inflacji ${ }^{18}$. Z kolei lata 1930-1935 stanowiły przedmiot dociekań Z. Knakiewicz ${ }^{19}$ i Z. Landaua ${ }^{20}$, który nadto przedstawił problemy skarbowości w latach 1936-193921. Finanse państwa

${ }^{10}$ K. Ostrowski, Finanse $i$ prawo...

11 Z. L and a u, Historia finansów..., s. 51 .

12 Ibidem, s. 52.

13 „Finanse” 1969, nr 4.

14 "Finanse" 1978, nr 12.

1s "Zeszyty Naukowe Akademii Ekonomicznej w Katowicach” 1993, nr 126.

16 "C. Kosikowski, Dzialalność prawodawcza w dziedzinie finansów w okresie Polski międzywojennej, „Zeszyty Naukowe Uniwersytetu Lódzkiego" 1974, ser. I: Nauki Humanistyczno-Spoleczne. Prawo", z. 106.

${ }^{17}$ Z. La d d a u, Skarbowość polska w latach 1918-1920, „Finanse” 1966, nr 2.

18 Warszawa 1967.

19 Z. K n a ki ewicz, Deflacja polska 1930-1935, Warszawa 1967.

20 Z. Land a u, Kryzys finansowy w Polsce w latach 1930-1935, „Finanse" 1969, nr 10.

${ }^{21}$ Z. Land a u, Skarbowość polska w latach nakrecania koniunkiury (1936-1939), „Finanse” 1986, nr $7 / 8$. 
z lat 1936-1939 były przedmiotem badań również M. Drozdowskiego ${ }^{22}$, natomiast problemy finansowe rządów parlamentarnych $w$ Polsce omówila A. Lityńska ${ }^{23}$.

3. Najobszerniejszą monografię dotyczącą prawa budżetowego II Rzeczypospolitej do 1931 r. napisał przed wojną T. Grodyński ${ }^{24}$. Prace powojenne podejmujące zagadnienia budżetu w Polsce międzywojennej są nieliczne. Wymienić należy tu artykuły: S. Kirkora: Uwagi na temat techniki i polityki budzetowej $w$ Polsce $e^{25}$ oraz A. W. Zawadzkiego: Budżet państwowy w zaraniu II Rzeczypospolitej (1918-1923). Sporo wiadomości o gospodarce budżetowej państwa po przewrocie majowym zawiera praca $Z$. Landaua i B. Skrzeszewskiej, z wyborem dokumentów dotyczących sprawy ministra skarbu G. Czechowicza, który za złamanie dyscypliny budżetowej zostal pociągnięty do odpowiedzialności konstytucyjnej przed Trybunałem Stanu ${ }^{26}$.

Inne, nieliczne opracowania obrazują gospodarke funduszową ${ }^{27}$ oraz finansowanie nauki ${ }^{28}$, wojska ${ }^{29}$, opieki społecznej i zdrowia $^{30}$.

4. Wśród prac przedwojennych poświęconych podatkom i polityce podatkowej wyróżniają się prace J. Lubowickiego ${ }^{31}$, które jednak nie ujmują całego okresu Polski międzywojennej (kończą się na latach 1927-1928).

${ }^{22}$ M. Drozdowski, Polityka gospodarcza rzadu polskiego 1936-1939, Warszawa 1963; te nże, Uwagi o polityce walutowo-pieniężnej rzqdu polskiego w latach 1936-1939, ,Roczniki Dziejów Społecznych i Gospodarczych" 1961, t. 20.

${ }^{23}$ A. L i t y ń sk a, Problemy finansowe rzq̨ów parlamentarnych II Rzeczypospolitej, ,Zeszyty Naukowe Akademii Ekonomicznej w Krakowie" 1992, nr 389.

${ }^{24} \mathrm{~T}$. Grodyński, Zasady gospodarstwa budżetowego w Polsce na tle porównawczym, Kraków 1932.

${ }^{25}$ "Ekonomista Polski” 1945, nr 14-15.

${ }^{26}$ Z. Landau, B. Skrzeszewska, Sprawa Gabriela Czechowicza przed Trybunalem Stanu. Wybór dokumentów, Warszawa 1961.

${ }^{27} \mathrm{~J}$. B r ożek, Gospodarka funduszowa w Polsce $w$ dwudziestoleciu międzywojennym, „Studia Finansowe” 1975, nr 20.

${ }^{28}$ B. J a czewski, Organizacja i finansowanie nauki polskiej $w$ okresie międzywojennym, Wrocław 1971.

${ }^{29}$ K. Krzyżan ow ski, Wydatki wojskowe Polski w latach 1918-1939, Warszawa 1976; t en że, Wydatki wojskowe Polski miedzywojennej w liczbach, „Wojskowy Przegląd Ekonomiczny" 1967, nr 1; W. Ję d r zeje wicz, Fundusz Obrony Narodowej w czasie drugiej wojny światowej, „Zeszyty Historyczne" 1962, nr 1; K. K r zyżan ow ski, L. S z y mán ski, Jak finansowano obrone Polski w przededniu września, „Wojsko Ludowe”1960, nr 9; M. J a bło nowski, $Z$ problematyki finansów wojennych Polski lat 1936-1939, „Finanse” 1986, nr 5.

${ }^{30} \mathrm{E}$. W i eczor e k, Rola budżetu państwa $w$ finansowaniu wydatków na opieke spoleczna $w$ okresie przedwojennym $i$ w Polsce Ludowej, „Finanse” 1959, nr 9; t e n $\dot{z}$ e, Źródla finansowania wydatków na zdrowie w Polsce przedwrześniowej $i$ w Polsce Ludowej, „Finanse” 1960, nr 11.

${ }^{31}$ J. Lu bowicki, Polityka podatkowa Polski, Poznań 1927; te nże, Zasady reformy podatkowej, Warszawa 1928. 
Publikacjami powojennymi są artykuły: J. Szpunara Polityka podatkowa Polski $w$ okresie kryzysu $w$ latach 1929-193332, Z. Knakiewicz Polityka podatkowa w Polsce w okresie kryzysu 1930-1935'33, M. Mieszczankowskiego Podatki rolne $w$ Polsce miedzywojennej $j^{34}$, J. Ciepielowskiego Finansowe problemy wsi $w$ Polsce międzywojennej ${ }^{35}$, I. Bolkowiak i M. Majewicz Opodatkowanie wsi $w$ Polsce miedzywojennej ${ }^{36}$, C. Kosikowskiego Opodatkowanie przedsiębiorstw panstwowych $w$ Polsce międzywojennej ${ }^{37}$, E. Wojciechowskiego Problematyka interwencjonizmu podatkowego $w$ publikacjach międzywojennych ${ }^{38}$, R. Tomaki Konstrukcje dochodu podatkowego w ustawodawstwie Polski miedzywojennej ${ }^{39}$, J. Serwackiego Opodatkowanie nabycia spadków $w$ Polsce miedzywojennej $j^{40}$ oraz $\mathbf{M}$. Walugi Opodatkowanie zagranicznych podmiotów gospodarczych w latach $1918-1939^{41}$. Natomiast analizą postępowania wymiarowego przed i po wydaniu ordynacji podatkowej w $1934 \mathrm{r}$. zajął się R. Mastalski ${ }^{42}$.

5. Zagadnienia prawa i polityki celnej podejmuje przedwojenna praca S. F. Królikowskiego Zarys polityki handlowej ${ }^{43}$. Opracowania powstałe po wojnie podejmujące tę problematykę sq̨ autorstwa B. Hajduka ${ }^{44}$. Natomiast sprawom monopoli skarbowych w całym okresie II Rzeczypospolitej poświęcił obszerną monografię W. Mateńko ${ }^{45}$; a później problematyka ta nie stanowila już przedmiotu dociekań.

32 „Roczniki Dziejów Społecznych i Gospodarczych" 1958, t. 20.

33 „Finanse" 1965, nr 3.

34 „Roczniki Dziejów Ruchu Ludowego" 1961, nr 3.

35 „Finanse" 1969, nr 5.

36 „Finanse" 1982, nr 10

37 "Zeszyty Naukowe Uniwersytetu Lódzkiego" 1971, ser. I: Nauki Humanistyczno-Społeczne. Prawo, z. 83.

38 „Finanse" 1972, nr 10.

39 "Acta Universitatis Lodziensis" 1978, ser. I: Nauki Humanistyczno-Społeczne. Folia Iuridica, nr 32.

40 „Finanse" 1981, nr 4.

41 „Finanse" 1984, nr 10.

42 R. M a stalski, Wymiar podatków w Polsce w latach 1918-1934, „Acta Universitatis Wratislaviensis" 1976, Przegląd Prawa i Administracji, t. 7; te nż e, Ochrona interesu podatnika $w$ postepowaniu wymiarowym wedlug ordynacji podatkowej z 15 marca $1934 \mathrm{r}$,, ,Acta Universitatis Wratislaviensis" 1973, Przegląd Prawa i Administracji, t. 4.

43 Warszawa 1938

44 B. H ajd u k, Wolne Miasto Gdańsk w polityce celnej Polski 1922-1934, Wroclaw 1981; t e nż e, Polski system celny w latach 1919-1924, „Roczniki Dziejów Społecznych i Gospodarczych" $1992 / 1995$, t. $53 / 55$.

${ }_{45}$ W. Mateńk o Zagadnienie monopolów skarbowych w Polsce, Warszawa 1939. 
6. Największe zainteresowanie badaczy budziły dotąd zagadnienia pożyczek zagranicznych; pierwszy problematyką tą zająl się po wojnie L. Grosfeld ${ }^{46}$, zaś wśród prac powstałych później dominują opracowania $Z$. Landaua ${ }^{47}$. Natomiast pożyczkami wewnętrznymi zajmowała się $\mathbf{M}$. Ciechocińska ${ }^{48}$.

7. Dzieje administracji skarbowej w Polsce do 1930 r. przedstawil B. Markowski ${ }^{49}$. Szczególnie dużo miejsca Autor ten poświęcił analizie organizacji i pozycji ustrojowej władz skarbowych według stanu prawnego na $1930 \mathrm{r}$. Później zagadnienie to podejmowali: C. Kosikowski ${ }^{50}$, A. Witkowski, który zajął się również organami ochrony skarbowej zwalczającej przestępstwa skarbowe $^{51}$, oraz W. Burkiewicz ${ }^{52}$. Z kolei zagadnienie parlamentarnej kontroli długów państwa, sprawowanej przez Komisję Kontroli Długów Państwa w latach 1923-1939, przedstawił M. Pietrzak ${ }^{53}$.

${ }^{46}$ L. Grosfeld, Kredyty zagraniczne w Polsce przedwrześniowej, „Nowe Drogi”" 1948, $\mathrm{nr} 3$.

${ }^{47}$ Z. Landa u, Pożyczka tytoniowa, „Zeszyty Szkoły Głównej Planowania i Statystyki" 1959, nr 15; te nż̀ e, Pożyczka dillonowska. Przyczynek do dzialalności kapitalów amerykańskich w Polsce, „Kwartalnik Historyczny” 1957, nr 3; te nż e, Pożyczki zagraniczne w polityce rządu polskiego (XI 1920-XII 1923), „Przegląd Historyczny” 1959, nr 4; te nż e, Pierwsza polska pożyczka emisyjna w Stanach Zjednoczonych, „Zeszyty Szkoły Głównej Planowania i Statystyki" 1959, nr 15; tenże, Wladyslaw Grabski a pożyczki zagraniczne, „Kwartalnik Historyczny" 1959, $\mathrm{nr} 4$; tenże, Polskie zagraniczne pożyczki państwowe 1918-1926, Warszawa 1961; tenże, Miejsce pożyczek zagranicznych $w$ rzq̨dowych programach sanacji finansowej po przewrocie majowym, „Najnowsze Dzieje Polski. Studia i Materiały z Okresu 1914-1939” 1963, nr 6; t e ṅ̇e, Pożyczki zagraniczne państwa polskiego 1918-1939, „Finanse” 1969, nr 6; t e nże, Plan stabilizacyjny 1927-1930. Geneza, zalożenia, wyniki, Warszawa 1963. Zob. też A. D r wiłło, Zagraniczne pożyczki państwowe na tle systemu dochodów $i$ wydatków Polski międzywojennej, Gdańsk 1978.

${ }^{48} \mathrm{M}$. Ciechocińska, Pożyczki wewnetrzne emitowane przez rzqdy polskie $w$ latach 1933-1939, „Najnowsze Dzieje Polski. Studia i Materiały z Okresu 1914-1939” 1960, nr 2.

49 B. M a rkowski, Administracja skarbowa w Polsce, Warszawa 1930 (II wydanie tej książki ukazało się nakładem Wyższej Szkoły Handlowej w Kielcach im. B. Markowskiego w 2001 r.).

${ }^{50}$ C. Kos i k ow s ki, Pozycja prawna Ministra Skarbu w Polsce miedzywojennej, „Finanse” 1973 , nr 8.

${ }^{51}$ A. Witk owski, Ochrona Skarbowa w Polsce w latach 1936-1939, „Finanse 1986, nr 11-12; tenże, Ochrona Skarbowa w Polsce. Centrum Ksztalcenia Kadr Skarbowości Ministerstwa Finansów, Białobrzegi 1998; t e n ż e, Izby skarbowe i podlegle im organy administracji skarbowej w II Rzeczypospolitej, [w:] $Z$ dziejów skarbowości w Polsce od XVII do XX wieku, Kielce 2001; tenże, Dzialalność ubezpieczeniowa izb skarbowych w Polsce międzywojennej $i w$ latach 1944-1950, „Rzeszowskie Zeszyty Naukowe. Prawo-Ekonomia” 2001, ser. Prawnicza, t. XXX.

${ }^{52}$ W. Burkiewicz, Organizacja $i$ dzialalność wladz celnych $w$ przedwojennej Gdyni, „Rocznik Gdyński” 1986, nr 7.

${ }^{53}$ M. Pietrzak, Kontrola dlugów państwa w II Rzeczypospolitej, „Czasopismo Prawno-Historyczne" 1985, nr 2. 
Największym zainteresowaniem autorów cieszą się dzieje Najwyższej Izby Kontroli, która była uprawniona $\mathrm{m}$. in. do kontroli administracji państwowej pod względem finansowym, badania zamknięć rachunków państwowych oraz przedstawiania sejmowi wniosków $w$ przedmiocie absolutorium dla rządu ${ }^{54}$.

Sporo informacji na temat skarbowości II Rzeczypospolitej dostarczaja wspomnienia i pamiętniki osób zajmujących czołowe stanowiska w resorcie skarbu ${ }^{55}$ oraz prace powstałe później, opisujące ich działalnośćs ${ }^{56}$.

8. Należy wymienić tu prace N. Gajl Zasady systemu finansowego skomercjalizowanych przedsięiorstw państwowych $w$ Polsce miedzywojennej ${ }^{57}$

${ }^{54}$ Zob.: L. K u rowski, H. S o ch a ck a, R. S zaw low ski, Kontrola finansowa, Warszawa 1956; J. J a n i a k, Z dziejów Najwyższej Izby Kontroli 1919-1921, „Kontrola Państwowa” 1967, nr 6; t enże, $Z$ dziejów Najwyższej Izby Kontroli 1921-1924, „Kontrola Państwowa” 1968, nr 1; tenże, $Z$ dziejów Najwyższej Izby Kontroli 1924-1926, „Kontrola Państwowa” 1968, nr 3; J. Ziembiński, Polska kontrola państwowa $w$ XIX w. $i w$ Drugiej Rzeczypospolitej, „Acta Universitatis Nicolai Copernici” 1985, Nauki Humanistyczno-Społeczne. Prawo, nr 24; te nże, Najwyższa Izba Kontroli w Drugiej Rzeczypospolitej, [w:] Wybrane problemy prawa konstytucyjnego, red. W. Skrzydło, Lublin 1985; S. K ału żn y, J. Szcze paniak, Kontrola państwowa $w$ Polsce. Geneza $i$ rozwój naczelnych organów 1808-1980, Warszawa 1980; T. Owcza rek, Rys historyczny kontroli państwowej w Polsce, „Kontrola Państwowa” 1980, nr 2; A. S y lwe st r zak, Najwyższa Izba Kontroli w Drugiej Rzeczypospolitej, „Czasopismo Prawno-Historyczne" 1992, nr 1/2; te nż̇e, Najwyższa Izba Kontroli, Warszawa 1997; L G a r li ck i, Narodziny $i$ ksztaltowanie sie kontroli państwowej w niepodleglej Polsce, „Kontrola Państwowa” 1999, nr 2; Z. Witk owski, Pozycja ustrojowa i zadania Najwyższej Izby Kontroli w okresie 80-lecia, „Kontrola Państwowa” 1999, nr 2; D. G ó r e ck i, Pozycja ustrojowa Najwyższej Izby Kontroli w II Rzeczypospolitej, "Kontrola Państwowa” 2000, $\mathrm{nr} 6$; A. M lynarczyk, Kontrola $i$ nadzór nad finansami w II Rzeczypospolitej, „Finanse Komunalne” 2000, nr 2.

ss Zob. L. Biliński, Wspomnienia i dokumenty, Warszawa 1925; W. G rabski, Dwa lata pracy u podstaw państwowości naszej (1924-1925), Warszawa 1927; R. Łyczywek, Tarapaty trzech ministrów skarbu, „Nowe Prawo” 1958, nr 4; W. M. Z a wadzki, Polityka finansowa Polski $w$ okresie 1931-1935, do druku przygot. Z. Landau, J. Tomaszewski, „Kwartalnik Historyczny” 1965, nr 1; A. I vanka, Wspomnienia skarbowca (1927-1945), Warszawa 1964.

s6 J. Zi eli ński, Boleslaw Markowski 1862-1936, Kraków 1967; Z. Landa u, Feliks Mlynarski 1884-1972. Zarys życia i dzialalności na polu finansów, „Finanse” 1973, nr 11 te nże, Ignacy Matuszewski (1891-1946). Kierownik Ministerstwa Skarbu, „Finanse 1974”, nr 5; t e nże, Jerzy Michalski (1870-1956), „Finanse” 1974, nr 2; t e nż e, Czeslaw Klarner (1872-1957). Minister skarbu oraz minister przemyslu i handlu, „Finanse” 1975, nr 1; t e n ż e, Hubert Ignacy Linde (1867-1926). Minister skarbu, minister poczt i telegrafów, prezes Pocztowej Kasy Oszczędności, „Finanse” 1975, nr 5; t e nże, Pierwszy kierownik Ministerstwa Skarbu II Rzeczypospolitej, „Finanse” 1978, nr 10; te n że, Pamiętniki ministrów skarbu II Rzeczypospolitej jako źródlo badań nad historiq finansów, „Finanse” 1979, nr 4; t e nże, W. Zawadzki (1885-1939). Ekonomista - polityk - minister skarbu, „Przegląd Historyczny” 1980, nr 4.

57 „Zeszyty Naukowe Uniwersytetu Lódzkiego” 1958, ser: I: Nauki Humanistyczno-Społeczne, $\mathrm{nr} 8$ 
i C. Kosikowskiego Formy prawno-finansowe przedsiębiorstw państwowych w Polsce miedzywojennej ${ }^{58}$.

9. Zagadnienia ewolucji ustroju pieniężnego w niemal całym dwudziestoleciu międzywojennym zdążyły być przedmiotem publikacji, które zostały wydane do września 1939 r. Należy tu wymienić prace J. Zdziechowskiego ${ }^{59}$ (pełnil funkcje ministra skarbu w latach 1925-1926) oraz T. Solowija ${ }^{60}$. Powojenne opracowania książkowe $\mathrm{w}$ tym zakresie są dziełem: J. Tomaszewskiego ${ }^{61}$, Z. Karpińskiego ${ }^{62}$, Z. Żabińskiego ${ }^{63}$ i J. Zajdy ${ }^{64}$, z kolei artykuły o tejże tematyce opublikowali: K. Sztajer ${ }^{65}$, Z. Karpiński ${ }^{66}$, Z. Landau ${ }^{67}$, J. Fiszer ${ }^{68}$ oraz J. Lemczewski ${ }^{69}$.

10. Historię bankowości w II Rzeczypospolitej do 1932 r. obrazuje przedwojenna praca H. Nowaka Bankowość w Polsce ${ }^{70}$. Powojenne publikacje podejmują problematykę bankowości w sposób całościowy bądź poświęcone są dziejom poszczególnych banków. Do pierwszej grupy zaliczyć należy monografię W. Morawskiego Bankowość prywatna w II Rzeczypospolitej $j^{71}$, cykl artykułów Z. Landaua: Bankowość polska w latach 1924-192972, Dzialalność banków $w$ Polsce $w$ latach wielkiego kryzysu gospodarczego

${ }^{58}$ „Zeszyty Naukowe Uniwersytetu Lódzkiego” 1968, ser: I: Nauki Humanistyczno-Społeczne. Prawo, nr 57.

59 J. Zdziechowski, Mit zlotej waluty, Warszawa 1937.

${ }^{60}$ T. Solowij, Rynek pieniężny i stopa procentowa w Polsce, Warszawa 1939.

${ }^{61}$ J. Tomaszewski, Stabilizacja waluty w Polsce 1924-1925, Warszawa 1961.

${ }^{62}$ Z. Karpiński, Ustroje pieniężne w Polsce od roku 1917, Warszawa 1968.

${ }^{63} \mathrm{Z}$. Żabiński, Systemy pienięzne na ziemiach polskich, Kraków 1981.

${ }^{64} \mathrm{~J} . \mathrm{Z}$ ajda, Kierunki polityki walutowej Polski w okresie międzywojennym, Warszawa 1986.

${ }^{65}$ K. S z t a je r, Waluta Polski przedwrześniowej, „Finanse” 1952, nr 5.

${ }^{66} \mathrm{Z}$. K a r piński, Zmiany ustroju pieniężnego $w$ Polsce $w$ okresie między 1918-1950, „Wiadomości Narodowego Banku Polskiego" 1958, nr 11; t e n ż e, Tworzenie ustroju pieniężnego w Polsce po pierwszej wojnie światowej, „Najnowsze Dzieje Polski. Materiały i Studia z Okresu 1914-1939" 1966, nr 10; t e nż e, Przeobrażenia niektórych funkcji pieniqdza w Polsce w ubieglym piéćdziesięcioleciu, „Wiadomości Narodowego Banku Polskiego” 1967, nr 4.

${ }^{67}$ Z. L a nd a u, Reformy skarbowo-walutowe Wladyslawa Grabskiego (1924-1925), ,Finanse" 1969, nr 3; tenże, Polityka pienięzna Polski w okresie wielkiego kryzysu gospodarczego (1930-1935), „Finanse” 1976, nr 9; t e n ż e, Inflacja w Polsce po I wojnie światowej, „Finanse” 1980, nr 2; tenże, Polityka walutowa rzqdu polskiego w latach 1936-1939, „Przegląd Historyczny" 1986, nr 2.

68 J. F is z e r, Reglamentacja dewizowa w Polsce w latach 1919-1939, „Finanse” 1985, nr 7/8.

${ }^{69} \mathrm{~J}$. L e m c z ew ski, Papiery wartościowe w praktyce lat przedwojennych, ,Bank i Kredyt” $1988, \mathrm{nr} 8 / 9$

${ }^{70}$ Warszawa 1932.

71 Warszawa 1996.

72 „Bank i Kredyt” 1970, nr 4. 
(1930-1935 $)^{73}$, Bankowość polska w latach 1936-193974, Polska bankowość prywatna $w$ okresie inflacji $7^{75}$ i Glówne tendencje rozwojowe bankowości w II Rzeczypospolitej $j^{76}$ oraz artykuły: Z. Karpińskiego Bankowość polska przed pięćdziesięciu laty ${ }^{77}, \mathrm{Z}$. Fedorowicza Początki dzialalności kredytowej w Polsce przedwrześniowej $^{78}$, W. Jaworskiego System kredytowy Polski kapitalistycznej ${ }^{79}$, R. Ślązaka Banki polskie II Rzeczypospolitej ${ }^{80}$ oraz A. Niezgody Rodzaje $i$ formy prawne banków ( $w$ świetle doświadczeń okresu międzywojennego $)^{81}$.

Z kolei opracowań swych dziejów (obszernych, bądź zwięzłych) doczekały się: Bank Polski ${ }^{82}$, Państwowy Bank Rolny ${ }^{83}$, Bank Handlowy w Warszawie S. A. ${ }^{84}$, Bank Gospodarstwa Krajowego (czéściowo) ${ }^{85}$, Pocztowa Kasa Oszczędności ${ }^{86}$, spółdzielnie oszczędnościowo-pożyczkowe ${ }^{87}$, Powszechna Kasa Oszczędności ${ }^{88}$ i niektóre lokalne banki i instytucje oszczędnościowo-pożyczkowe ${ }^{89}$.

73 „Finanse” 1976, nr 6.

${ }^{74}$ "Bank i Kredyt" 1986, nr 6.

75 "Wiadomości Narodowego Banku Polskiego" 1966, nr 5.

76 „Bank i Kredyt” 1978, nr 11.

77 „Wiadomości Narodowego Banku Polskiego" 1968, nr 11.

78 Ibidem.

79 „Wiadomości Narodowego Banku Polskiego" 1957, nr 7-8.

80 "Przegląd Techniczny" 1988, nr 8.

81 "Studia Prawnicze” 1995, nr 1/4.

${ }_{22}$ Z. K a r piński, Bank Polski 1924-1939, Warszawa 1958; R. W. K as zubski, Bank Polski S.A. - bank centralny II Rzeczypospolitej, „, Bank i Kredyt” 1995, nr 9.

${ }^{83}$ M. N owak, Państwowy Bank Rolny w Drugiej Rzeczypospolitej, „Zeszyty Naukowe Uniwersytetu Jagiellońskiego" 1988, Prace Prawnicze, nr 128.

${ }^{84}$ Z. Landau, J. T om a szewski, Bank Handlowy w Warszawie S.A. Historia i rozwój 1870-1970, Warszawa 1970.

${ }^{85} \mathrm{C}$. Urbański, Finansowanie inwestycji przemyslowych przez $B G K$ w okresie międzywojennym, „Inwestycje i Kredyt” 1957, nr 11 i 12, 1958, nr 1 i 2; M. Nowak, Zasady systemu kredytowego Banku Gospodarstwa Krajowego w okresie miedzywojennym, „Zeszyty Naukowe Uniwersytetu Jagiellońskiego" 1976, Prace Prawnicze, nr 70.

${ }_{86}$ Z. Landa u, Powstanie Pocztowej Kasy Oszczędności na tle istniejacych warunków politycznych i sytuacji gospodarczej Polski, „Bank i Kredyt” 1989, nr 4 -5.

${ }_{87} \mathrm{~F}$. K ęd z i or k ow a, $Z$ zagadnien malopolskiej spóldzielczości oszczędnościowo-pożyczkowej $w$ okresie międzywojennym, „Studia Historyczne” 1968, nr 2; J. M a je wski, Spóldzielczośc oszczędnościowo-pożyczkowa w Wielkopolsce i na Pomorzu 1918-1939, Warszawa 1965; T. R om a n ow ski, 70 lat spóldzielczości oszczędnościowo-pożyczkowej, „Trybuna Spółdzielcza” 1960, nr 12; T. W y s zo mi r k i, 100 lat spóldzielczości oszczędnościowo-pożyczkowej. Przyczynek do badań nad historiq S.O.P., „Wiadomości Narodowego Banku Polskiego” 1967, nr 3.

${ }_{88}$ M. A nd r zeje ws ki, Powszechna Kasa Oszczędności 1919-1989 (krótki rys historyczny), „Bank i Kredyt” 1989, nr 4-5. W. Bień, 60 lat powszechnych kas oszczedności, „Bank i Kredyt" 1979, nr 1.

${ }_{89}$ Z. C z a ja, Bank Spóldzielczy Sp. z o.o.w Gorlicach, „Roczniki Województwa Rzeszowskiego"' 1962/63; A. Jazdon, 100 lat Banku Spóldzielczego Oszczędnościowo-Pożyczkowego w Gostyniu, Warszawa 1965; R. K rygier, Bank Spóldzielczy w Szamotulach w latach 1866-1966, Szamotuly 1966; S. Ochociński, Podstawy organizacyjne i zarys rozwoju Banku 
Zagadnieniom bankowości towarzyszą bezpośrednio kwestie kredytu ${ }^{90}$.

11. Wśród opracowań książkowych wydanych przed wojną wyróżniają się prace A. Pragiera Zarys skarbowości komunalnej" oraz S. Pawlaka Prawo o finansach komunalnych ${ }^{92}$. Cennym źródłem wiedzy o przebiegu i rezultatach akcji na rzecz poprawy finansów samorządu terytorialnego jest Sprawozdanie Centralnej Komisji Oszczędnościowo-Oddlużeniowej dla Samorząó w ${ }^{93}$, powołanej w 1934 r. i działającej do 1937 r.

Książki podejmujące problematykę finansów samorządu terytorialnego opublikowali po wojnie: K. Niemski (Gospodarka finansowa samorzqdu terytorialnego $i$ kredyt komunalny ${ }^{94}$ ), A. W. Zawadzki (Finanse samorzqdu terytorialnego w latach 1918-193955) oraz R. Ciałkowski (Gospodarka budzetowa organów lokalnych $w$ Polsce 1918-199096). Z kolei artykuły podejmujące zagadnienia finansów komunalnych napisali: $H$. Sochacka- Krysiakowa $^{97}$, R. Ciałkowski ${ }^{98}$, A. W. Zawadzki ${ }^{99}$, L. Kurowski ${ }^{100}$,

Ludowego w Poznaniu, „Roczniki PTE w Poznaniu” 1965/66, t. 18; 75 lat Banku Spóldzielczego „Bank Rolników" w Opolu, red. S. Senft, Opole 1986; J. Smiałowski, Zduńskowolskie instytucje oszczędnościowo-pożyczkowe i banki w latach 1902-1939, „Rocznik Lódzki” 1996, nr 43.

${ }_{90}$ Zob. Z. Kozłowski, Kredyı rolny w Polsce przedwrześniowej, „Finanse” 1952, nr 2; te nże, Kredyt rolny w Polsce burżuazyjnej i w Polsce Ludowej, Warszawa 1955; M. M i eszczankowski, Zadlużenie rolnictwa w Polsce międzywojennej, „Najnowsze Dzieje Polski. Materiały i studia z okresu 1914-1939" 1963, nr 3; t e nż e, Ciezzary kredytu rolnego w Polsce międzywojennej, „Ekonomista" 1969, nr 1; K. Pi ot rowska-H ochfeldowa, Stosunki kredytowe na wsi w Polsce burżuazyjno-obszarniczej $i$ w Polsce Ludowej, „Ekonomista” 1954, nr 4; T. Kow a la k, Zagraniczne kredyty dla Niemców w Polsce 1919-1939, Warszawa 1972; M. Now a k, Etatyzacja systemu kredytowego w latach 1919-1929 a tendencje totalistyczne państwa polskiego, „Zeszyty Naukowe Uniwersytetu Jagiellońskiego" 1976, Prace z Nauk Politycznych, nr 9; M. N ow ak, T. Włu d y k a, Rynek kredytowy w Drugiej Rzeczypospolitej, Kraków 1993.

${ }^{91}$ Warszawa, cz. I - 1924, cz. II - 1926.

${ }^{92}$ Warszawa 1937.

${ }_{93}$ Warszawa 1937.

${ }_{94}$ Łódź 1946.

${ }^{95}$ Warszawa 1971.

96 Katowice 1991.

${ }^{97} \mathrm{H}$. S ochacka-K rysiak owa, Ksztaltowanie sie systemu dochodów podatkowych samorzqdu terytorialnego w Polsce mięzywojennej, „Zeszyty Szkoły Głównej Planowania i Statystyki" 1960, nr 13.

${ }_{98}$ R. Ci i łk ow ski, System prawno-finansowy samorzqdu terytorialnego w Polsce w latach 1918-1939, „Zeszyty Naukowe Uniwersytetu Lódzkiego” 1967, ser. I: Nauki Humanistyczno-Społeczne. Prawo, z. 52.

${ }^{99}$ A. W. Zawad z k i, Finanse samorzqdu terytorialnego $w$ latach 1918-1923, „Finanse” 1969, nr 1.

${ }^{100}$ L. K u rowski, Rozwój systemu finansowego gminy wiejskiej w Polsce 1918-1974, „Studia Iuridica” 1975, z. 3. 
J. Słaby ${ }^{101}$, P. Laskowski ${ }^{102}$, A. Borodo ${ }^{103}$, A. Młynarczyk ${ }^{104}$, R. Kowalczyk ${ }^{105}$ oraz M. Podkowski ${ }^{106}$. Problematykę komunalnych kas oszczędności podjęli zaś J. Basta ${ }^{107}$ i A. Młynarczyk ${ }^{108}$. L Góral przybliżył zagadnienie kredytu komunalnego ${ }^{109}$, L. Kalkowski zajął się obligacjami komunalnymi ${ }^{110}$, a $Z$. Landau poruszył problem kredytów zaciągniętych przez dziesięć miast w konsorcjum amerykańskim $\mathrm{H}$. Ulena ${ }^{111}$, natomiast $\mathrm{T}$. Dębowska-Romanowska dokonała analizy metod organizacji i finansowania przedsiębiorstw komunalnych ${ }^{112}$. Nadto powstało kilka prac traktujących o finansach poszczególnych miast ${ }^{113}$.

101 J. S ła b y, System finansowy samorzqdu terytorialnego w latach 1918-1939, „Organizacja - Metody - Technika" 1990, nr 3.

${ }_{102}$ P. La sk owski, Źródla finansowania dzialalności samorzq̨du terytorialnego w Polsce międzywojennej, ,Zeszyty Naukowe Uniwersytetu Opolskiego" 1996, nr 22.

${ }^{103}$ A. B o rodo, Finanse samorzqdu terytorialnego w Drugiej $i$ Trzeciej Rzeczypospolitej, „Zeszyty Naukowe WSHE Włocławek” 1999, nr 4.

${ }^{104}$ A. M łynarczyk, Finanse samorzadow powiatowych w II Rzeczypospolitej, „Zeszyty Naukowe Uniwersytetu Szczecińskiego" 1999, Roczniki Prawnicze, nr 10.

${ }^{105}$ R. K owalczyk, System budżetowy gmin w II Rzeczypospolitej, „Acta Universitatis Wratislaviensis" 2001, Przegląd Prawa i Administracji, nr 46.

${ }^{106}$ M. Podk owski, Podatki samoistne $w$ gminach wiejskich $w$ latach 1933-1939 (na przykladzie Wielkopolski), „Acta Universitatis Wratislaviensis” 2001, nr 273.

${ }^{107} \mathrm{~J}$. B a s t a, Prawne podstawy dzialania komunalnych kas oszczędności w II Rzeczypospolitej, [w:] Przez tysiqclecia: państwo - prawo - jednostka, 1. 2, red. A. Lityński, M. Mikołajczyk, Katowice 2001.

${ }^{108}$ A. M ły narczyk, Dzialalność komunalnych kas oszczędności w II Rzeczypospolitej, „Samorząd Terytorialny” 2001, z. 7/8.

${ }^{109}$ L. G ó ra l, Instytucja kredytu komunalnego w II Rzeczypospolitej, "Samorząd Terytorialny" 1993, $\mathrm{nr} 11$.

${ }^{110}$ L. K alk owski, Tradycje polskich obligacji komunalnych, „Samorząd Terytorialny” 1995 , nr 3.

${ }^{111}$ Z. La nda u, Pożyczki ulenowskie, „Najnowsze Dzieje Polski. Studia i Materiały z Lat 1914-1939" 1958, t. 1 .

112 T. Dę bowska-R om a nowska, Metody organizacji $i$ finansowania przedsiębiorstw komunalnych w Polsce międzywojennej, „Zeszyty Naukowe Uniwersytetu Lódzkiego" 1970, ser. I: Nauki Humanistyczno-Społeczne. Prawo, z. 73.

113 A. Szczypiorski, Od Piotra Drzewieckiego do Stefana Starzyńskiego. (Gospodarka komunalna m. st. Warszawy w latach 1915-1939), Wroclaw 1968; A. Wernik, Finanse m. st. Warszawy w okresie kryzysu ekonomicznego w latach 1929-1934, „Finanse” 1956, nr 1; B. Puczyński, Ogólny zarys wplywu wielkiego kryzysu 1929-1932 na gospodarke gminy m. Czestochowy, „Zeszyty Naukowe Politechniki Częstochowskiej” 1964, Nauki SpołecznoEkonomiczne, nr l; E. K r z e mi én, Gospodarka i dzialalność Zarzqdu Miejskiego m. Poznania w latach 1918-1939 w świetle sprawozdań budzetowych, Poznan 1967; J. M a r zuk, Źródla i struktura dochodów miasta Lublina w latach 1918-1939, „Finanse” 1976, $\mathrm{nr} 8$; te nże, Gospodarka finansowa samorzqdu miasta Lublina w latach 1918-1939, „Roczniki Dziejów Społecznych i Gospodarczych" 1978, t. 39; E. Ada m czyk, Gospodarka komunalna miasta Krakowa w okresie II Rzeczypospolitej, Kraków 1997. 
Zaprezentowane zestawienie dorobku badań skarbowości Polski międzywojennej, prowadzonych po II wojnie światowej dowodzi, że od czasu ich oceny dokonanej przez Z L Landaua w $1970 \mathrm{r}$. powiększył się on o przeszło 80 prac. Mimo iż nadal utrzymują się duże dysproporcje w szczegółowości i kompletności opracowań poszczególnych działów skarbowości, to skala poczynionych ustaleń winna sklaniać - jak się wydaje - do przygotowania syntezy przybliżającej całość owej problematyki. 